\title{
INTELLECTUAL CAPITAL DISCLOSURE IN BANKING COMPANY AT INDONESIA STOCK EXCHANGE
}

\author{
Calvina Wijayanti ${ }^{1}$ \\ Adriana Marini Purwanto ${ }^{2}$ \\ S. Patricia Febrina Dwijayanti ${ }^{3}$ \\ Widya Mandala Catholic University Surabaya \\ patricia@ukwms.ac.id
}

\section{A R T I C L E I N F O \\ Article history: \\ Received : 8 August 2019 \\ Revised : 26 August 2019 \\ Accepted : 20 September 2019}

Key words:

Intellectual capital, leverage, profitability, company age, listing age

DOI:

ttps://doi.org/10.33508/rima.v2i2.2605

\begin{abstract}
A B S T R A C T
Intellectual capital is one of intangible asset's component that can provide an added value to the company. Intellectual capital disclosure in the company's annual reports can help to provide a complete information for investors in predicting the performance of the company for making an economic decisions. In addition, intellectual capital disclosure can also show the good performance of a company to attract investors. Intellectual capital disclosure can be affected by several factors, such as leverage, profitability, company age, and listing age. This study aims to obtain empirical evidence and analyze the effect of leverage, profitability, company age, and listing age on intellectual capital disclosure. The sample used in this study are banking companies listed in Indonesia Stock Exchange. The number of samples in this study are 95 companies and selected using purposive sampling. Hypothesis testing are using multiple linear regression analysis. Based on the results of the hypothesis testing, the results of this study show that profitability, company age, and listing age have a significant positive effect on intellectual capital disclosure, while leverage have no significant effect on intellectual capital disclosure.
\end{abstract}

\section{INTRODUCTION}

Today, the era of globalization requires a renewal of corporate strategy in the face of competition in an increasingly competitive business world. This causes the company to change its business strategy based on labor (labor-based business) towards a market that is based on knowledge (knowledge-based industry) to continue to survive (Sawarjuwono and Kadir, 2003). While using technology and science, it can be obtained how to use other resources efficiently and economically, which will give a competitive advantage (Rupert, 1998; in Sawarjuwono and Kadir, 2003). Company assets are often associated with physical resources or tangible assets, so that knowledge resources (or so-called intellectual capital) are less considered. In contrast, a company's success can be seen from the knowledge and competence of human resources so that the company can compete competitively in conducting its business activities. At present, the awareness and need for the importance of intellectual capital are higher, along with increasing competition between companies in doing business activities (Sangkala, 2006; in Faradina, 2015). A company can develop and last long can be seen from its ability to adapt more quickly to the demands of the times using innovations that can direct it to its goals. This capability is only possible if the company effectively uses knowledge 
resources or intellectual capital (Sangkala, 2006; Faradina, 2015).

The definition of intellectual capital, according to Bontis (1998, in Utomo and Chariri, 2015), is everything that exists in a company related to intangible resources, including the processes carried out by companies in processing these resources. The phenomenon of intellectual capital in Indonesia began to develop after the emergence of PSAK no. 19 (revised 2000) concerning intangible assets (Yuniasih, Wirama, and Badera, 2010). In PSAK, no. 19 (revised 2000) has indirectly alluded to intellectual capital, which shows that intellectual capital has begun to receive attention. However, the disclosure of intellectual capital has not been done by all companies. This is because intellectual capital has more intangible assets, causing difficulties in managing, measuring, and reporting (Nugroho, 2012). Companies in Indonesia often do not pay attention to the three components of intellectual capital: human capital, structural capital or organizational capital, and relational capital or customer capital (Sawarjuwono and Kadir, 2003). To compete in the knowledgebased business era, the three components of intellectual capital are needed to create added value for the company (Sawarjuwono and Kadir, 2003). The significant role of intellectual capital in the current economic era when human resources and science are a source of corporate competitive advantage is also a reason for the importance of intellectual capital ownership by a company (Chen, 2005; in Cahya, 2013).

Disclosure of intellectual capital in financial statements is essential in helping to provide complete information for stakeholders in predicting company performance for economic decision making. Lev and Zarowin (1999; in Suhardjanto and Wardhani, 2010) found that many studies have shown that the current accounting model cannot reveal the critical factor of the company's long term value. That is intangible resources so that financial statements are considered to fail in describing the broad range of intangible asset values. Several other researchers have also found a large gap between market value and book value revealed because the company has failed to report "hidden value" in its annual report (Mouritsen et al., 2004; in Suhardjanto and Wardhani, 2010). This can lead to information asymmetry between companies and users of financial statements (Barth et al., 2001; Suhardjanto and Wardhani, 2010). Therefore, an appropriate approach to improve the quality of financial statements is to encourage increased information on intellectual capital disclosure (Canibano et al., 2000; Suhardjanto and Wardhani, 2010). Disclosure of intellectual capital in a financial statement is a way to disclose the report explaining the company's activities that are credible, integrated, and "true and fair" (Faradina, 2015). Bukh et al. (2003; in Suhardjanto and Wardhani) states that some form of intellectual capital disclosure is valuable for investors, which can help reduce uncertainty about prospects and facilitate the accuracy of the assessment of the company.

Disclosure of intellectual capital can also show better financial performance (Saleh et al., 2007; Suhardjanto and Wadhani, 2010). Disclosure of intellectual capital is also influenced by various factors related to company characteristics (Suhardjanto and Wardhani, 2010). These factors can be in the form of leverage, profitability, age of the company, and company listings on the IDX. Companies with high leverage levels tend to have high agency costs to reduce agency costs companies can disclose more information voluntarily, including information about intellectual capital (Purnomosidhi, 2006). This relates to agency theory (agency 
theory), which states that the way to reduce the cost of the trust arising from conflicts between managers and shareholders increases the extent of the disclosure (Purnomosidhi, 2006). Also, substantial company profitability shows higher company performance. Companies tend to disclose more open information about intellectual capital to differentiate themselves from other companies and provide investment signals to investors (Sutanto and Supatmi, 2012). This relates to signaling theory (signaling theory), which states that high-performance companies use financial information to send signals to the market (Spence, 1973; in Suhardjanto and Wardhani, 2010).

Furthermore, companies with an older age show the company (going concern) in the business world, so that broader disclosures are also made relating to creating confidence in outsiders about the company (Nugroho, 2012). The age of company listing on the IDX is also one of the factors affecting intellectual capital disclosure. Companies that have an older listing age will tend to disclose more information, including information about disclosure of intellectual capital. After all, the company has more experience to understand better the information needs of stakeholders relating to the company (Rahmawati, 2012: 187; in Soebyakto, Agustina, and Mukhtaruddin, 2015).

This phenomenon of intellectual capital demands more detailed information on matters relating to intelligent capital disclosure. Several reasons support this research interesting to do in the annual report companies go public in Indonesia. First, the launching of a government program on providing tax incentives for companies conducting research and development processes since 2003, is expected to increase corporate attention to the importance of intellectual capital, which is voluntary disclosure of intellectual capital
(Suhardjanto and Wardhani, 2010). Second, no standard sets the items included in intangible assets that can be managed, measured, and reported, reporting mandatory disclosure and voluntary disclosure (Nugroho, 2012). Third, based on a global survey conducted by PriceWaterhouseCoopers, it turns out that information about a company's intellectual capital is five of the ten types of information that users need (Eccles et al., 2001; in Suhardjanto and Wardhani, 2010). However, in reality, the kind of information considered by investors is not disclosed, causing an "information gap" (Bozzolan et al., 2003; in Suhardjanto and Wardhani, 2010). Fourth, based on the results of research conducted by Suhardjanto and Wardhani (2010) shows that the area of intellectual capital disclosure in Indonesia is still low at an average of only $34.5 \%$ of the total 25 items of intellectual capital disclosure. Therefore, there is a need for research on the practice of intellectual capital disclosure in Indonesia, especially by going public companies listed on the Indonesia Stock Exchange (IDX). Various previous studies have been conducted to examine the factors that influence the broad disclosure of intellectual capital in the annual report. Oktavianti and Wahidahwati (2014) found that profitability and company age significantly affected the area of intellectual capital disclosure, but did not prove a significant effect on leverage. Meanwhile, Faradina (2015) found that the three independent variables, namely leverage, profitability, and age of the company, did not significantly influence the area of intellectual capital disclosure. Also, research conducted by Suhardjanto and Wardhani (2010) found that profitability had a significant effect on the extent of intellectual capital disclosure, but did not provide evidence that leverage and the age of company listings on the IDX influenced the scope of intellectual capital disclosure. 


\section{LITERATURE REVIEW}

\section{Agency Theory}

Jensen and Meckling (1976: in Utomo and Chariri, 2015) define agency theory as the relationship between principal and agent. This agency theory arises because of the separation between the company owner (principal) and the company managers (agent). As companies grow to become large, moreover, shareholders are increasingly dispersed, more agency costs are incurred, and owners are increasingly unable to exercise effective control over managers who manage the company (Prasetyo, 2009: 11; in Oktavianti and Wahidahwati, 2014). The separation of ownership between the owner (principal) and management (agent) can lead to agency conflict caused by differences in preferences and goals. The difference in perception between the principal and agent will lead to the emergence of information asymmetry. Management that tends to have more information has an excellent opportunity to take actions that can harm the owner. Oktavianti and Wahidahwati (2014) stated that the information gap occurs because the manager interacts daily with the company's activities to be acutely aware of the company's conditions. Thus the manager has complete information about the company he manages. Whereas company owners only rely on management reports, company owners do not interact directly with company activities, so company owners have only a portion or less information than company managers.

Agency theory places disclosure as a mechanism that can reduce costs resulting from conflicts between managers and shareholders (compensation contracts) and disputes between companies and their creditors (debt contracts) (Suhardjanto and Wardhani, 2010). Disclosure of information can also reduce the emergence of information asymmetry between the principal and agent because disclosure can provide confidence in the knowledge that reflects the company's performance. Therefore, exposure is a mechanism to control the manager's performance. Consequently, managers are encouraged to voluntarily disclose information, such as intellectual capital disclosure (Suhardjanto and Wardhani, 2010).

\section{Signaling Theory}

Agustini (2011; in Cempaka and Marsono, 2013) states that signaling theory is a theory that explains how signals of success or failure of management (agent) are conveyed to the owner (principal). This signaling theory is based on information asymmetry in the market (Morris, 1987; in Utomo and Chariri, 2015). Information asymmetry occurs when managers have more internal company information and know that information faster than external parties (Setianingrum, 2015). This information asymmetry can also be said as an information gap between principals and agents regarding financial and non-financial information in a company. To reduce the information asymmetry, the company will disclose the data held in the company's annual report, both financial and nonfinancial information, one of which is the disclosure of intellectual capital (Setianingrum, 2015). The benefits of reporting intellectual capital to the principal are to provide information to understand the company's current condition better and provide an understanding of the strategy and how it uses its sources of intellectual capital (Utomo and Chariri, 2015). The information can also reduce information asymmetry between the principal and the agent to minimize agency problems.

Signaling theory also states that high-performance companies use financial information to send signals to the market (Spence, 1973; in Suhardjanto and Wardhani, 2010). Therefore, addressing this 
signal makes managers more motivated to disclose intellectual capital as private information voluntarily. This is due to managers' expectations that providing the right message about the company's performance to the market will reduce information asymmetry (Oliveira et al., 2008; in Suhardjanto and Wardhani, 2010). When the company's positive signal gets a positive response from the market, stakeholder evaluations of the company also increase (Utomo and Chariri, 2015).

\section{Intellectual Capital}

Intellectual capital is knowledge and other intangible assets that produce or create present value or future value (Viedma, 2007; in Lina, 2013). Intellectual capital is often expressed as knowledge resources in the form of employees, customers, processes, or technology that companies can use to create value for the company (Bukh et al., 2005; in Oktavianti and Wahidahwati, 2014). Intellectual capital is the knowledge that can provide benefits to the company. According to Lina (2013), the benefit of intellectual capital is contributing something and contributing that can add value and usefulness for the company. According to Setianingrum (2015), in general, intellectual capital is divided into three main components, namely:

\section{a. Human capital}

Human capital reflects the company's collective ability to produce the best solutions based on people's knowledge. Human capital can be referred to as lifeblood in intellectual capital because this is where the source of innovation and improvement is located but is a challenging component to measure. Human capital is also a useful source of knowledge, skills, and competencies in an organization or company. Human capital is inherent in each person so that it cannot be owned by the company. It also includes how effectively a company uses its employees as measured by the creativity and innovation of the workforce. Human capital will increase if the company can use the knowledge possessed by its employees.

b. Organizational capital or structural capital

Organizational capital is the ability of an organization or company to fulfill the company's routine processes and structures that support employees' efforts to produce optimal intellectual performance and overall business performance, for example, operational systems.

The company, manufacturing process, organizational culture, management philosophy, and all forms of intellectual property owned by the company.

c. Relational capital or customer capital

Relational capital, or also called customer capital, is a component of intellectual capital that provides real value. Relational capital is a good relationship between the company and its partners, both from reliable and quality suppliers, from loyal customers and satisfied with the company's services, from its relationship with the government and the surrounding community.

The components of intellectual capital above are indicative of future value and the company's ability to produce financial performance (Purnomosidhi, 2006). Intellectual capital gives the company a massive opportunity for the company to increase its value through profit generation, strategic positioning (market share, leadership, reputation), acquisition of innovations from other companies, customer loyalty, cost reduction, and increased productivity (Purnomosidhi), 2006). A successful company is a company that can maximize the value of its intellectual capital.

Intellectual Capital Disclosure 
In general, there are two types of disclosures, namely mandatory disclosures and voluntary disclosures. Necessary disclosure is the disclosure of information required by applicable regulations or standards, whereas voluntary disclosure is the disclosure of information that exceeds the required disclosure. Disclosure of intellectual capital is part of voluntary disclosure (voluntary disclosure). Exposure of intellectual capital is believed to be a factor driving and creating corporate value (Ulum, 2011; Sutanto and Supatmi, 2012). Intellectual capital refers to non-physical, intangible, or invisible capital related to human knowledge, experience, and the technology used (Rupidara, 2008; Ramananda and Nugrahanti, 2014). Intellectual capital is considered to provide substantial economic benefits in the future.

Companies disclose their intellectual capital based on various reasons. According to Widjanarko (2006; in Nugroho, 2012), there are five reasons companies report intellectual capital:

1. Reporting on intellectual capital can help organizations formulate business strategies. By identifying and developing an organization's intellectual capital to gain a competitive advantage.

2. Reporting on intellectual capital can lead to the development of key indicators of company performance that will help evaluate the results of achieving the strategy.

3. Reporting on intellectual capital can help evaluate company mergers and acquisitions accurately to determine the acquirer's price.

4. Using non-financial intellectual capital reporting can be linked to intensive plans and company compensation.

5. Communicate with external stakeholders about

intellectual property owned by the company.

Leverage
Leverage is the number of assets measured by debt financing, where debt here is not from investors or shareholders, but creditors (Nugroho, 2012). Companies with a high proportion of debt in their capital structure will bear higher agency costs than companies with a small portion of the debt (Oktavianti and Wahidahwati, 2014). This is in line with agency theory, which states that the way to reduce agency costs arising from conflicts between managers and shareholders is to increase the extent of the disclosure (Purnomosidhi, 2006). Therefore, to reduce agency costs, management is expected can disclose more information as the level of leverage increases. Agency theory predicts that firms with higher leverage ratios will reveal more details because the agency costs of companies with such capital structures are higher (Jensen and Meckling, 1976; in Oktavianti and Wahidahwati, 2014). A high degree of leverage requires companies to eliminate bondholders' doubts about the security of their funds by disclosing information (Utomo and Chariri, 2015).

\section{Profitability}

Petronila and Mukhlasin (2003; in Sutanto and Supatmi, 2012) state that profitability is a picture of management performance in managing a company. Profitability is one way to measure company performance. Profitability ratios indicate a company's ability to generate profits about sales, total assets, and equity (Sutanto and Supatmi, 2012). Return On Assets (ROA) is one indicator of a company's success in generating profits. The higher the profitability, the higher the ability to generate profits for the company (Oktavianti and Wahidahwati, 2014). Return On Assets (ROA) can measure the company's ability to generate profits using the company's total assets after adjusting with costs used to fund these assets, such as developing and managing employees in 
increasing intellectual capital (Rachmawati, 2012; in Oktavianti and Wahidahwati, 2014). High profitability is one thing that is considered reasonable by the company. Therefore, it will tend to be disclosed in detail by the company (Sutanto and Supatmi, 2012). Companies with a high level of profitability tend to publish more, one of which is voluntary disclosure of intellectual capital. This is because companies with a high profitability level tend to want to show excellent company performance to increase investor confidence and company value. Ahmed and Courtis (1999; in Purnomosidhi, 2006) argue that this phenomenon is based on the signaling hypothesis, which states that superior and profitable firms tend to reveal more information to investors.

\section{Company Age}

The age of the company in this study is the length of the company established or operated until this year. The company's age is the beginning of the company's operational activities to maintain the company's going concerned or maintain its existence in the business world (Oktavianti and Wahidahwati, 2014). According to Marwata (2001; in Sutanto and Supatmi, 2012), older companies more in-depth knowledge about the needs of their constituents for information about the company. This causes older companies will tend to disclose more detailed information, including details about intellectual capital, to attract investors. Therefore, Nugroho (2012) states that the longer the company's life, the more visible the company (going concerned), so the broader the disclosure made is related to creating confidence outside parties in the quality of the company.

\section{Age of Listing}

The age of listing in this study is the length of time the company began listing (first issue) on the Indonesia Stock Exchange (IDX) until this year. The age of company listings on the IDX shows how long it has been able to compete and take advantage of business opportunities in the economy (White, et al., 2007; in Soebyakto, et al., 2015). Therefore, companies with an older listing age will tend to make more extensive disclosures than companies with a younger listing age. Companies with an older listing age have more experience involuntary exposure of intellectual capital in annual reports (Soebyakto et al. ., 2015). Besides, companies with an older listing age have more knowledge so that more understand the information needs of stakeholders relating to the company (Rahmawati, 2012; 187; in Soebyakto, et al., 2015).

Hypothesis Development

Effect of Leverage on the Disclosure of Intellectual Capital Disclosures

Jensen and Meckling (1976) suggest that there is a potential for transferring wealth from debtholders to shareholders and managers in companies whose levels of dependence on debt are very high, resulting in senior agency costs (Purnomosidhi, 2006). Agency theory predicts that companies with higher leverage ratios will reveal more information about intellectual capital because of the high level of financial risk they face (Jensen and Meckling, 1976; in Oktavianti and Wahidahwati, 2014). More comprehensive disclosures, including disclosure of intellectual capital, will reduce information asymmetry between managers and creditors. The higher the leverage of a company, the more disclosure of intellectual capital is disclosed in annual reports (Utomo and Chariri, 2015). Research conducted by Soebyakto et al. (2015) shows that leverage significantly influences the extent of intellectual disclosure. Soebyakto research results et al. (2015) provides evidence that companies with high leverage 
ratios have obligation to meet long-term creditors' information needs so that companies will tend to make disclosures and reduce agency costs. This shows that the higher the leverage, the higher the intellectual capital disclosure will be. Based on the description above, the hypotheses that can be formulated are:

H1: Leverage has a positive effect on the area of intellectual capital disclosure

Effect of Profitability on the Disclosure of Intellectual Capital Disclosures

Haniffa and Cooke (2005; in Suhardjanto and Wardhani, 2010) showed that the higher the level of profitability, the more voluntary disclosure of information to the public. This optional information disclosed to the public includes disclosure of intellectual capital. High corporate profitability indicates higher company performance. Companies tend to communicate more open details on intellectual capital to differentiate themselves from other companies and provide investment signals to investors (Sutanto and Supatmi, 2012). This is in line with the signaling theory (signaling theory), which states that high-performance companies use financial information to send signals to the market (Spence, 1973; in Suhardjanto and Wardhani, 2010). Profitability is also one measure; it is essential to assess companies that can influence investors' decision-making. The test used to measure profitability is Return on Assets (ROA). Several previous studies conducted by Oktavianti and Wahidahwati (2014) and Suhardjanto and Wardhani (2010) showed that profitability significantly affected intellectual capital disclosure. This indicates that the higher the profitability, the greater the exposure of intellectual capital. Based on the description above, the hypotheses that can be formulated are:
H2: Profitability has a positive effect on the area of intellectual capital disclosure

Effect of Company Age on Disclosure of Intellectual Capital Disclosure

According to Marwata (2001; in Sutanto and Supatmi, 2012), older companies have more profound knowledge about their constituents' needs for information about the company. Therefore, the longer the company's life, the more visible the existence of the company (going concerned), so the broader the disclosure made to create confidence to outsiders related to the quality of the company (Nugroho, 2012). Comprehensive disclosure of information can also reduce information asymmetry and provide an excellent signal to the market (signaling theory). Research conducted by Oktavianti and Wahidahwati (2014) showed that company age significantly affected the area of intellectual capital disclosure. This shows the older generation of the company, the more extensive the exposure of intellectual capital. Based on the description above, the hypotheses that can be formulated are:

H3: Company age has a positive effect on the area of intellectual capital disclosure

Effect of Age of Listing on the Extent of Disclosure of Intellectual Capital

Companies with an older listing age will tend to make broader disclosures than companies with a younger listing age because companies with an older listing age have more experience involuntary exposure of intellectual capital in annual reports (Soebyakto et al., 2015). Also, companies with an older listing age have more experience, so they better understand the information needs of stakeholders relating to the company (Rahmawati, 2012; 187; in Soebyakto, et al., 2015). Therefore, the older the company's age, the more information is disclosed, including details about intellectual capital. The more information 
disclosed, the higher the level of investor confidence in the company is expected. This is in line with signaling theory, which can reduce information asymmetry between management and investors by making broader disclosures, especially disclosures relating to intellectual capital. Research conducted by Soebyakto et al. (2015) shows that the age of company listings on IDX has a significant effect on the area of intellectual capital disclosure. This indicates that the older the companies listing on the IDX, the more extensive the exposure of intellectual capital. Based on the description above, the hypotheses that can be formulated are:
H4: Age of listing has a positive effect on the extent of intellectual capital disclosure

\section{$\underline{\text { Research Model }}$}

This research model illustrates the relationship between the dependent variable: the extent of intellectual capital disclosure in banking companies with the independent variables, namely leverage, profitability, company age, and age of listings. Based on the formulation of a hypothesis, the following Figure 1 shows the relationship between variables in this research model

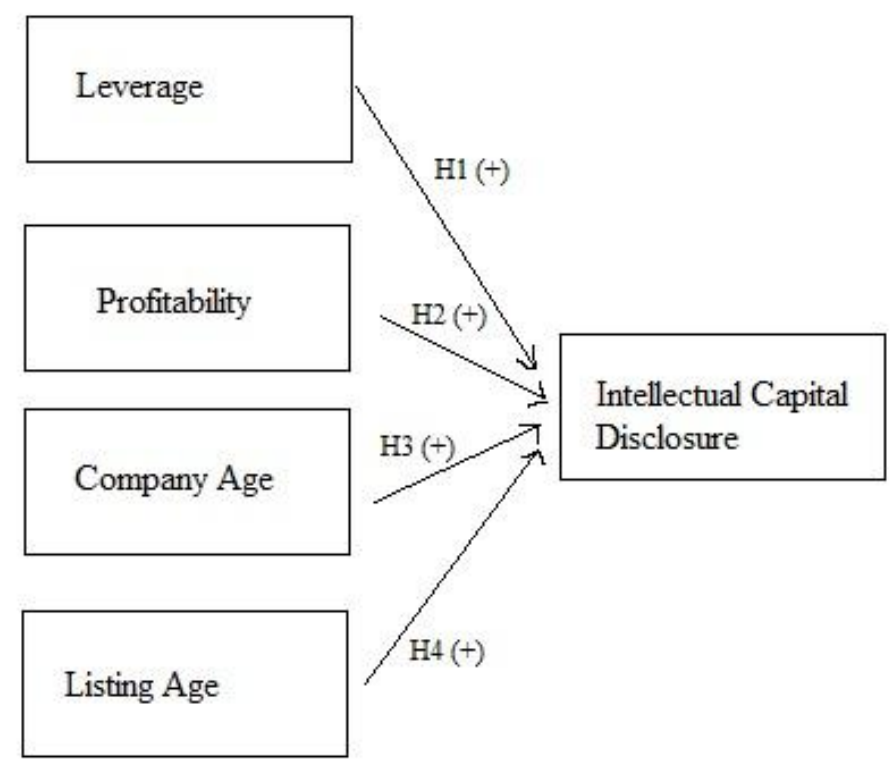

Figure 1 Framework Research

\section{METHODOLOGY}

$\underline{\text { Research design }}$

The design of this research is research with hypothesis testing. This quantitative research was conducted to obtain empirical evidence and analyze the influence of the factors that influence intellectual capital disclosure.

Variable Identification, Operational Definition, and Variable Measurement

Disclosure of Intellectual Capital
Intellectual capital disclosure in this study was measured using an index of intellectual capital disclosure (ICD Index) totaling 78 items developed by Bukh et al. (2005; in Oktavianti and Wahidahwati, 2014). The ICD Index assesses the extent of a company's intellectual capital disclosure by giving a value of 1 for items disclosed by the company in the annual report and 0 for details not published by the company. Score $=\mathrm{d}_{\mathrm{i}} / \mathrm{N}$

Score: index intellectual capital 
$\mathrm{d}_{\mathrm{i}}$ : total capital intellectual company

$\mathrm{N}$ : sample (78 item)

\section{Leverage}

Leverage is the ratio between the number of assets financed with debt. The leverage ratio shows the ability of a company's assets to meet all company obligations. This measurement of leverage refers to the research of Sutanto and Supatmi (2012). Leverage $=$ total debt $/$ total asset

\section{Profitability}

Profitability is an indication of management's performance in managing company assets to generate profits. The calculation of profitability uses the basis of the return rate on assets using the Return on Asset (ROA) formula. This profitability measurement uses the method (Utari, Purwanti, and Prawironegoro, 2014). ROA $=$ total earning $/$ total asset

\section{Company age}

Measurement of company age in this study refers to research conducted by Permono (2011). The company's age is calculated from the date the company was first established until the time of the last financial statement (research) is carried out, which is rounded up in a matter of years. Company Age = Tglt - Tgln

Tglt : the date of observation

$\operatorname{Tgl} n$ : the date of establishment company

\section{Age of listing}

According to Suhardjanto and Wardhani (2010), the listing age is calculated from the date listed on IDX until the last date financial statement, which was rounded up in a matter of years. Calculation of listing age refers to the study by Suhardjanto and Wardhani (2010)

\section{$\underline{\text { Data Types and Sources }}$}

The type of data used in this study is quantitative data. Quantitative data is data that can be measured on a numerical scale or number. This quantitative data was obtained through annual reports and financial statements of banking companies listed on the Indonesia Stock Exchange in 2013-2015.

The data source used in this study is secondary data. Secondary data is already available in the form of data that has been processed and published by other parties. This secondary data was obtained from the IDX website (www.idx.co.id).

\section{Population}

The population used in this study is banking companies listed on the Indonesia Stock Exchange (IDX) in 2013-2015. The sampling technique in this study uses purposive sampling method to get a representative sample according to predetermined criteria. The following are sample criteria in this study:

a. Banking sector companies listed successively on the Stock Exchange for 2013-2015.

b. The company published a full annual report and financial report for the years 2013-2015.

\section{$\underline{\text { Technique Analysis Data }}$}

The data analysis technique used in this study is a multiple linear regression analysis. This multiple linear regression analysis is used to determine leverage, profitability, company age, and age of listings on intellectual capital disclosure. The multiple linear regression analysis equation models are as follows:

$\mathrm{DISC}=\alpha+\beta 1 \mathrm{LEV}+\beta 2 \mathrm{PROF}+$ $\beta 3$ COMPAGE $+\beta 4$ LISTAGE $+\mathrm{e}$

Information:

DISC: intellectual capital disclosure

a: constant

$\beta$ : linear regression coefficient

LEV: Debt to Asset Ratio 
PROF: Return On Asset (ROA)

COMPAGE: company age

LISTAGE: listing age

e: error

\section{RESULT}

\section{Characteristics Object}

This research used banking company listed Indonesia Stock

Table 1. Criteria Sample

\begin{tabular}{|l|l|}
\hline Criteria Sampling & Total \\
\hline Banking company listed until 2015 & 44 \\
\hline Company did not fulfill criteria: & \\
\hline 1. Listed 2013-2015 & $(1)$ \\
\hline 2. Create annual report and financial report completely & $(8)$ \\
\hline Total sample & 35 \\
\hline Observation period & 3 years \\
\hline Total data observation & 105 \\
\hline Outlier data & $(10)$ \\
\hline Total fix sample $(\mathrm{N})$ & 95 \\
\hline
\end{tabular}

Multiple Linear Regression

Multiple linear regression analysis was performed to determine the effect of leverage, profitability, company age, and age of listings on the area of

Table 2: Multiple Linear Regression

\begin{tabular}{|c|c|c|c|c|c|}
\hline $\begin{array}{l}\text { Variabel } \\
\text { Dependen }\end{array}$ & $\begin{array}{c}\text { Variabel } \\
\text { Independen }\end{array}$ & $\beta$ & $\begin{array}{l}\text { Std. } \\
\text { Error }\end{array}$ & $\mathrm{t}$ & Sig \\
\hline \multirow{9}{*}{$\begin{array}{l}\text { Intellectual } \\
\text { Capital } \\
\text { Disclosure }\end{array}$} & Constant & 0,366 & 0,167 & 2,201 & 0,030 \\
\hline & LEV & $-0,11$ & 0,191 & $-0,56$ & 0,955 \\
\hline & PROF & 2,485 & 0,870 & 2,855 & 0,005 \\
\hline & COMPAGE & 0,001 & 0,001 & 2,599 & 0,011 \\
\hline & LISTAGE & 0,003 & 0,001 & 2,478 & 0,015 \\
\hline & $\begin{array}{l}\text { R square } \\
\left(R^{2}\right)\end{array}$ & \multicolumn{4}{|l|}{0,301} \\
\hline & Adjusted $\mathrm{R}^{2}$ & \multicolumn{4}{|l|}{0,270} \\
\hline & $\mathrm{F}$ & \multicolumn{4}{|l|}{9,708} \\
\hline & Sig F & \multicolumn{4}{|l|}{0,000} \\
\hline
\end{tabular}

Based on Table 2 obtained by the multiple linear regression equation as follows:

DISC $=0.366+-0.11 \mathrm{LEV}+2,485 \mathrm{PROF}+$
Exchange 2013-2015 with total 129 company. Using purposive sampling method and ended up with 105 company as a sample in this research. But while heteroscedasticity there were 10 company as outlier. Then, sampling data for this research 95 company. intellectual capital disclosure. Here is a table 2, a summary of the results of multiple linear regression analysis using IBM SPSS Statistics 23:
0.001 COMPAGE + 0.003 LISTAGE + e The following is an explanation of the multiple linear regression equation above: 
The multiple linear regression equation shows the value of a (constant) of 0.366 and has a positive value. This value explains that if the independent variables, namely leverage, profitability, age of listings, and age of the company, are equal to 0 (zero) or constant, then the area of intellectual capital disclosure is 0.366 .

LEV variable regression coefficient (leverage) or $\beta 1=-0.11$. This value indicates that the magnitude of the effect of leverage on the area of intellectual capital disclosure is -0.11 . The negative coefficient of regression indicates that the higher the level of leverage, the wider the intellectual capital disclosure.

The regression coefficient of the PROF variable (profitability) or $\beta 2=$ 2,485 . This value indicates that the effect of profitability on the area of intellectual capital disclosure is 2,485. The positive, positive regression coefficient indicates that the higher the level of profitability, the higher the intellectual capital disclosure.

COMPAGE variable regression coefficient (age of the company) or $\beta 3=$ 0.001 . This value indicates that the magnitude of the effect of the company's age on the area of intellectual capital disclosure is 0.001 . A positive regression coefficient indicates that the older the company, the higher the intellectual capital disclosure will be.

LISTAGE variable regression coefficient (age of listing) or $\beta 3=0.003$. This value indicates that the magnitude of the effect of the age of listing on the area of intellectual capital disclosure is 0.003. A positive regression coefficient indicates that the older the listing age, the higher the intellectual capital disclosure will be.

a. Determination Coefficient Test $\left(\mathrm{R}^{2}\right)$

The determination test's coefficient aims to measure how far the model's ability to explain the variation of the dependent variable. The ratio of determination is between zero and one. Based on the test results of the coefficient of determination in Table 2 can be seen that the value of the coefficient of determination is equal to 0.301 or $30.1 \%$. This shows that the independent variables, namely leverage, profitability, company age, and age of listings, can explain the variable width of intellectual capital disclosure of $30.1 \%$. In comparison, $69.9 \%$ is explained by other variables not contained in this study.

\section{b. Model Feasibility Test (F Test)}

The model feasibility test ( $\mathrm{F}$ test)

aims to determine whether the independent variables included in the model affect the dependent variable so that the model can be said to be feasible. If the significance $<0.05$, then the regression model is said to be possible. Based on the results of the model feasibility test in Table 2, it can be seen that the significance value of $F$ is equal to 0,000 or $<0.05$. This shows that the independent variables, namely leverage, profitability, company age, and age of listings, influence the dependent variable, namely the area of intellectual capital disclosure so that the regression model is said to be feasible.

c. Hypothesis Test (t-test)

Hypothesis testing (t-test) is used to test the significance of the influence of the independent variables on the dependent variable. Based on the results of the hypothesis test in Table 2, it can be explained as follows:

Hypothesis test results of the influence of leverage on the area of intellectual capital disclosure produce a regression coefficient of -0.11 and a 
significance value of 0.955 . The significance value of the leverage variable is more significant than 0.05 , so it can be concluded that leverage has no significant effect on the area of intellectual capital disclosure.

Hypothesis test results of the effect of profitability on the area of intellectual capital disclosure produce a regression coefficient of 2.485 and a significance value of 0.005 . The significance value of the profitability variable is smaller than 0.05 , so it can be concluded that profitability has a significant effect on the area of intellectual capital disclosure.

Hypothesis test results of the influence of company age on the area of intellectual capital disclosure produce a regression coefficient of 0.001 and a significance value of 0.011 . The significance value of the company's age variable is less than 0.05 , so it can be concluded that the company's age has a significant effect on the area of intellectual capital disclosure.

Hypothesis test results of the effect of listing age on the intellectual capital disclosure area produce a regression coefficient 0.003 and a significance value of 0.015 . The significance value of the listing age variable is smaller than 0.05 , so it can be concluded that the listing age has a significant effect on the area of intellectual capital disclosure.

\section{Discussion}

Based on the results of hypothesis testing, it can be concluded that leverage has no significant effect on the area ofintellectual capital disclosure. In contrast, profitability, company age, and age of the listing have a significant impact on the field of intellectual capital disclosure. The following is a more detailed discussion of the results of the hypothesis testing of each variable:

Impact of Leverage on the Disclosure of Intellectual Capital Disclosures

The first hypothesis testing regarding the effect of leverage on the area of intellectual capital disclosure resulted in a regression coefficient of 0.11 and a significance value of 0.955 . Significance value above 0.05 can be interpreted as leverage that does not significantly affect the area of intellectual capital disclosure. Thus the first hypothesis which states that leverage positively influences the extent of intellectual capital disclosure is unacceptable.

The results of this study are in line with the results of research conducted by Suhardjanto and Wardhani (2010), Oktavianti and Wahidahwati (2014), and Faradina (2015) states that leverage does not have a significant effect on the area of intellectual capital disclosure. Suhardjanto and Wardhani (2010) noted that variable leverage is not a good predictor of the extent of intellectual capital disclosure. Besides, the measurement of leverage using the ratio of total debt divided by total assets less relevant is used for banking companies so that they are not able to measure the financial performance of banking companies correctly. This is due to the broad composition of debts to banking companies due to customer deposit accounts in the form of demand deposits, savings, or time deposits. Therefore, this study's results indicate that there is no significant relationship between leverage and the extent of intellectual capital disclosure in banking companies. On the other hand, the results of this study are not in line with the results of research conducted by Soebyakto et al. (2015), which states that leverage significantly influences the 
extent of intellectual capital disclosure. Soebyakto et al. (2015) argued that companies with high levels of force would tend to make broader intellectual capital disclosures to reduce agency costs that arise.

Effect of Profitability on the Disclosure of Intellectual Capital Disclosures

The second hypothesis testing regarding the effect of profitability on the area of intellectual capital disclosure produces a regression coefficient of 2.485 and a significance value of 0.005 . Significance value below 0.05 can be interpreted that profitability has a significant effect on the area of intellectual capital disclosure. Thus, the second hypothesis states that profitability has a positive impact on the extent of intellectual capital disclosure and can be accepted.

This study's results are in line with the results of research conducted by Suhardjanto and Wardhani (2010) and Oktavianti and Wahidahwati (2014), which state that profitability has a positive effect on the extent of intellectual capital disclosure. This shows that the higher the level of profitability, the company will tend to make broader disclosures. High corporate profitability also shows top company performance. Companies with a high profitability level tend to want to show excellent company performance to increase investor confidence and company value. Oktavianti and Wahidahwati (2014) stated that the amount of ROA indicates high returns for investors. That way, investors will be interested in investing their capital in the company so that the company will make broader intellectual capital disclosures to attract investors.

However, the results of this study are not in line with research conducted by Faradina (2015) and Soebyakto et al. (2015), who found that profitability did not affect the extent of intellectual capital disclosure.

Effect of Company Age on Disclosure of Intellectual Capital Disclosure

The third hypothesis testing regarding the influence of company age on the area of intellectual capital disclosure produces a regression coefficient of 0.001 and a significance value of 0.011 . Significance value below 0.05 can be interpreted that the age of the company has a significant effect on the area of intellectual capital disclosure. The direction of the company's age variable's regression coefficient is positive, which means companies with an older company age will disclose broader intellectual capital. Thus, the third hypothesis, which states that the company's generation has a positive effect on the extent of disclosure of intellectual capital, can be accepted.

The results of this study are in line with research conducted by Permono (2011), which states that company age has a significant effect on the extent of intellectual capital disclosure. The older the company, the company will provide more comprehensive disclosure of financial information than younger companies because the company has more experience in disclosing intellectual capital in the annual report (Permono, 2011).

On the other hand, the results of this study are not in line with Faradina (2015) research, which states that the age of the company does not significantly influence the extent of intellectual capital disclosure. Faradina (2015) argues that the company's period does not guarantee that the company has the experience and an understanding of 
disclosing intellectual capital. The older generation of the company does not necessarily show better the level of expertise and knowledge related to intellectual capital owned by the company so that the level of intellectual capital disclosure cannot be optimal.

Effect of Age of Listing on the Extent of Disclosure of Intellectual Capital

Testing the fourth hypothesis regarding the effect of listing age on the area of intellectual capital disclosure produces a regression coefficient value of 0.003 and a significance value of 0.015 . Significance value below 0.05 means that the age of the listing has a significant effect on the area of intellectual capital disclosure. The direction of the company's age variable's regression coefficient is positive, which means companies with an older listing age will disclose broader intellectual capital. Thus the fourth hypothesis states that the age of the listing has a positive effect on the extent of intellectual capital disclosure acceptable.

The results of this study are in line with Lina's (2013) research, which states that the more mature the age of company listings, the more extensive the disclosure of intellectual capital by the company. This is because companies with an older listing age have more knowledge and experience in disclosing information needed by the public so that companies will make more comprehensive, complete, and adequate disclosures (Lina, 2013)

However, the results of this study are not in line with research conducted by Suhardjanto and Wardhani (2010), which states that the age of listings does not affect the extent of intellectual capital disclosure. Suhardjanto and Wardhani (2010) state that the age of listings cannot be used as a guideline in predicting the level of reporting of intellectual capital so that age is not a reflection of experience and understanding in the disclosure of intellectual capital.

\section{RESULT}

Conclusion

Based on the results of research and discussion, it can be summed up as follows: 1. Leverage has no significant effect on area intellectual capital disclosure. This is due to leverage not being a good predictor of extensive intellectual capital disclosure, and measurement of the leverage used is not relevant for the company banks, so they cannot measure performance financial banking companies well.

2. Profitability has a positive effect on the area of intellectual capital disclosure. A company with a high level of profitability is likely to voluntarily conduct intellectual capital disclosure to show the company's performance that good and increase investor confidence.

3. The age of the company has a positive effect on the area of intellectual capital disclosure. With age, the older ones have the knowledge and experience more capital disclosure intellectuals in the annual report. 4. Age listing has a positive effect on area intellectual capital disclosure. A company with age listing on the older Indonesian Stock Exchange has more in-depth knowledge and experience to disclose information needed by the public, so the company will make disclosure more extensive, complete, and adequate.

\section{Suggestion}

Based on the limitations of this study, here are some suggestions for improvement in future research:

1. Use the intellectual capital disclosure checklist specifically intended for banking companies. 
2. Use specific financial ratios used to measure banking financial performance like the CAMEL method (Capital, Asset quality, Management, Earnings, Liquidity, and Sensitivity to market risk) or the RGEC (Risk profile, Good corporate way) governance, Earnings, and Capital).

\section{REFERENCE}

Cahya, H.M.P., 2013, Determinan Pengungkapan Luas Modal Intelektual pada Perbankan tahun 2009-2011, Accounting Analysis Journal, Vol. 3, No. 1, November: 471479.

Cempaka, M.D. dan Marsono, 2013, Analisis Faktor - faktor yang Mempengaruhi Intellectual Capital Disclosure dan Pengaruhnya Terhadap Cost Of Equity Capital (Studi Empiris Pada Perusahaan Real Estate Dan Properti yang Terdaftar di BEI Tahun 2009-2011), Diponegoro Journal of Accounting, Vol. 2, No. 4, Hal. 1-8.

Faradina, S., 2015, Faktor-faktor yang Mempengaruhi Pengungkapan Intellectual Capital pada Perusahaan Property dan Real Estate, Jurnal Bisnis dan Manajemen, Vol. 5, No. 2, Oktober: 305-326.

Ghozali, I., 2009, Ekonometrika: Teori, Konsep, dan Aplikasi Dengan SPSS 17, Semarang: Badan Penerbit Universitas Diponegoro.

Khaerunnisa, H., 2013, Pengaruh Pelayanan Prima terhadap Kepuasan Nasabah, Jurnal Studia Akuntansi dan Bisnis, Vol. 1, No. 1, Hal. 47-60.

Lina, 2013, Faktor-faktor Penentu Pengungkapan Modal Intelektual,
Media Riset Akuntansi, Vol. 3, No. 1, Februari: 48-64.

Nugroho, A., 2012, Faktor-faktor yang Mempengaruhi Intellectual Capital Disclosure (ICD). Accounting Analysis Journal. Vol. 1, No. 2, November: 111.

Oktavianti, H. dan Wahidahwati, 2014, Faktor-faktor yang Mempengaruhi Pengungkapan Intellectual Capital, Jurnal Ilmu dan Riset Akuntansi, Vol. 3, No. 5, Hal. 1-18.

Permono, Akin Setiawan dan Dr. H. Raharja, M.Si., Akt., 2011, Faktorfaktor yang Mempengaruhi Luas Pengungkapan Sukarela Modal Intelektual (Studi Empiris pada Perusahaan Keuangan yang Listing di BEI tahun 2010), Diponegoro University Institutional Repository, Hal 1-28.

Purnomosidhi, B., 2006, Praktik Pengungkapan Modal Intelektual Pada Perusahaan Publik di BEJ, Jurnal Riset Akuntansi Indonesia, Vol. 9, No. 1, Hal. 1-20.

Ramananda, D. dan Y.W. Nugrahanti, 2014, Analisis Pengungkapan Intellectual Capital Berdasarkan Profitabilitas, Leverage, dan Size Perusahaan (Perbandingan antara Perusahaan Perbankan di Indonesia dan Thailand), Dinamika Akuntansi, Keuangan, dan Perbankan, Vol. 3, No. 1, Salatiga: 84-98.

Sawarjuwono, T., dan A. Prihatin, 2003, Intellectual Capital: Perlakuan, Pengukuran dan Pelaporan (Sebuah Library Research), Jurnal Akuntansi dan Keuangan, Vol. 5, No. 1, Mei: 35-57. 
Setianingrum, H., 2015, Pengaruh Komponen Karakteristik Perusahaan Terhadap Intellectual Capital Disclosure (Studi Perusahaan Go Publik yang Tergabung dalam Indeks LQ-45 Tahun 2012 dan 2013 di BEI), Fakultas Ekonomi dan Bisnis, Universitas Dian Nuswantoro Semarang.

Soebyakto, B.B., M. Agustina dan Mukhtaruddin, 2015, Analysis of Intellectual Capital Diclosure Practises: Empirical Study on Services Companies Listed on Indonesia Stock Exchange, GSTF Journal on Bussiness Review (GBR), Vol. 4, No. 1, Juli: 80-96.

Suhardjanto, D. dan M. Wardhani, 2010, Praktik Intellectual Capital Disclosure Perusahaan yang Terdaftar di Bursa Efek Indonesia, Jurnal Akuntansi dan Auditing Indonesia, Vol. 14, No. 1, Juni: 71-85.

Sutanto, F.D. dan Supatmi, 2012, Pengaruh Karakteristik Perusahaan Terhadap Tingkat Pengungkapan Informasi Intellectual Capital di dalam Laporan Tahunan (Studi pada Industri Manufaktur yang Terdaftar di Bursa Efek Indonesia Tahun 2009), Jurnal Akuntansi Universitas Diponegoro, Hal 1-19.

Utari, Dewi, A. Purwanti, dan D. Prawironegoro, 2014, Manajemen Keuangan (Kajian Praktik dan Teori dalam Mengelola Keuangan Organisasi Perusahaan), Jakarta: Mitra Wacana Media.

Utomo, A.I. dan A. Chariri, 2014, Faktorfaktor yang Mempengaruhi Pengungkapan Modal Intelektual dan Dampaknya Terhadap Nilai
Perusahaan, Simposium Nasional Akuntansi XVIII, Hal. 1- 17.

Yuniasih, N.W., D.G. Wirama dan I.D.N. Badera, 2010, Eksplorasi Kinerja Pasar Perusahaan: Kajian Berdasarkan Modal Intelektual, Simposium Nasional Akuntansi XIII Purwokerto, Oktober: 1-29. 